\title{
Thyroglobulin Messenger Ribonucleic Acid Levels in the Peripheral Blood of Children with Benign and Malignant Thyroid Disease
}

\author{
CYDNEY FENTON, JEFFREY S. ANDERSON, ANEETA D. PATEL, YVONNE LUKES, \\ BARBARA SOLOMON, R. MICHAEL TUTTLE, MATTHEW D. RINGEL, AND GARY L. FRANCIS \\ From the Departments of Pediatrics [C.F., G.L.F.], Clinical Investigation [J.S.A., Y.L., B.S., R.M.T.], and \\ Medicine [R.M.T.], Walter Reed Army Medical Center, Washington, DC 20307, U.S.A.; Department of \\ Medicine, Washington Hospital Center and Medstar Research Institute, Washington, DC 20010, U.S.A. \\ [M.D.R.]; and Department of Pediatrics, F. Edward Hebert School of Medicine, Uniformed Services \\ University of the Health Sciences, Bethesda, Maryland 20814, U.S.A. [C.F., G.L.F.]
}

\begin{abstract}
Reverse transcriptase-PCR has identified thyroglobulin mRNA (Tg mRNA) in peripheral blood of normal adults and adults with thyroid cancer. However, no children were studied. The primary objective of this study was to determine whether whole blood Tg mRNA levels differ between benign and malignant thyroid disease in children. The secondary goals were to determine whether whole blood Tg mRNA levels vary with age or pubertal development among children with thyroid disease. Whole blood Tg mRNA levels were determined in 38 children (29 girls, nine boys; median age, $14.5 \mathrm{y}$; range, 4.8-20.4 y) with benign and malignant thyroid disease and correlated with diagnosis, age, pubertal status, thyroid size, and serum levels of free thyroxine, TSH, and Tg protein. Tg mRNA levels ranged from 3.3 to $104 \mathrm{pg} \mathrm{Eq/ \mu g}$ total thyroid RNA (mean, $28 \pm 20.2 \mathrm{pg}$ $\mathrm{Eq} / \mu \mathrm{g}$ total thyroid RNA) and were similar in benign and malignant disorders $(p=0.67)$. However, in children with previously treated papillary thyroid cancer, Tg mRNA levels
\end{abstract}

\section{ABSTRACT}

directly correlated with total body ${ }^{131}$ I uptake $(p=0.026)$ and serum Tg protein $(p=0.037)$. There was no difference between boys and girls, and no change with pubertal maturation. In children with benign thyroid disease, Tg mRNA levels correlated with serum TSH $(p=0.031)$, but not with diagnosis, age, Tanner stage, or thyroid size. We conclude that Tg mRNA levels are similar in children with benign and malignant thyroid disease and unchanged by age or pubertal status, but correlated with tumor burden in previously treated papillary thyroid cancer. (Pediatr Res 49: 429-434, 2001)

Tg, thyroglobulin

Abbreviations:

PTC, papillary thyroid cancer

RT-PCR, reverse transcriptase-PCR

$\mathbf{T}_{\mathbf{4}}$, free thyroxine
RT-PCR has been used in recent studies to identify unique, tissue-specific mRNA products in the peripheral blood of patients with several different cancers. This has now been used for melanoma (1), breast cancer (2), prostate cancer (3), and most recently, differentiated thyroid cancer (4-6).

Our own group has developed a quantitative PCR technique that uses fluorescent probes and the quantitative ABI-PRISM 7700 Sequence Detection System to quantify the thyroid-

Received May 1, 2000; accepted October 16, 2000.

Correspondence and reprint requests: Gary L. Francis, M.D., Ph.D., Department of Pediatrics, Uniformed Services University of the Health Sciences, 4301 Jones Bridge Rd, Bethesda, MD 20814 U.S.A.

Supported by the Department of Clinical Investigation, Walter Reed Army Medical Center (WU \#1392).

The opinions or assertions contained herein are the private views of the authors and are not to be construed as official or to reflect the opinion of the Uniformed Services University of the Health Sciences, the Department of the Army, or the Department of Defense. specific Tg mRNA in the peripheral blood of normal adults and adults with thyroid cancer $(7,8)$. These studies have shown that normal adults have serum Tg mRNA levels ranging from 3 to $84 \mathrm{pg} \mathrm{Eq} / \mu \mathrm{g}$ total thyroid RNA. Subjects with benign thyroid diseases have similar levels, as do subjects with residual or recurrent thyroid cancer $(7,8)$. In contrast, adults rendered completely athyreotic (total thyroidectomy plus radioactive iodine ablation) and who are free of disease generally have serum Tg mRNA levels $<3 \mathrm{pg} \mathrm{Eq/ \mu g}$ total thyroid RNA (8). This technique has now been used to confirm the presence of residual thyroid cancer in a number of subjects, and has the potential to be of use in monitoring thyroid cancer patients for detection of recurrent disease (8). This is especially true for individuals with circulating anti-Tg antibodies that interfere with most serum $\mathrm{Tg}$ protein assays (9).

To our knowledge, no previous study has investigated $\mathrm{Tg}$ mRNA levels in the peripheral blood of children. We hypoth- 
esized that whole blood Tg mRNA levels would differ between children with benign and malignant thyroid disease. We also questioned whether Tg mRNA levels would be affected by age or pubertal status. The primary objective of this study was to determine whether whole blood Tg mRNA levels differ in children with benign and malignant thyroid disease. The secondary goals were to determine whether $\mathrm{Tg}$ mRNA levels correlate with diagnosis, age, pubertal status, size of the thyroid gland, and serum levels of $\mathrm{T}_{4}, \mathrm{TSH}$, or $\mathrm{Tg}$ protein in children with thyroid disorders.

\section{METHODS}

This study received prior approval from the Institutional Review Board and the Human Use Committee of the Department of Clinical Investigation, Walter Reed Army Medical Center, Washington, DC, U.S.A. The study was funded by an intramural research grant (WU\#1392) from the Department of Clinical Investigation, Walter Reed Army Medical Center.

A total of 42 consecutive subjects were recruited from the Pediatric Endocrine Clinic, Walter Reed Army Medical Center, Washington, DC, U.S.A. Four subjects were excluded from the study because intact RNA could not be isolated from the blood sample obtained. Of the final 38 patients, there were 29 girls and nine boys with a median age of $14.5 \mathrm{y}$ (range, 4.8-20.4 y). Eighteen patients with Hashimoto's thyroiditis (evidenced by diffuse goiter with positive anti-thyroid peroxidase antibodies), 12 with Graves' disease (evidenced by diffuse goiter, hyperthyroidism, and positive TSH receptor antibodies), five with previously treated PTC (World Health Organization Classification System) (10), two with multinodular goiter (evidenced by multiple nodules $>0.5 \mathrm{~cm}$ identified by ultrasound and including patients with positive or negative anti-thyroid peroxidase antibodies), and one normal subject were studied. Hypothyroidism was suspected in the latter patient but excluded by laboratory evaluation. Serum TSH levels were suppressed $[<0.5 \mu \mathrm{U} / \mathrm{mL}$, third-generation chemiluminescent TSH assay (normal range, 0.5-4.9 $\mu \mathrm{IU} / \mathrm{mL}$ ), Quest, Nichols Institute, San Juan Capistrano, CA, U.S.A.] in nine patients, normal $(0.5-4.9 \mu \mathrm{U} / \mathrm{mL})$ in 19 patients, and elevated $(>5.1$ $\mu \mathrm{U} / \mathrm{mL}$ ) in the remaining 10 . The mean $\mathrm{T}_{4}$ level ranged from $<3.0$ to $36.6 \mathrm{pM}$ (mean, $14.4 \pm 7.9 \mathrm{pM}$ ). Four patients had detectable anti-Tg antibody.

After informed consent, each subject had a thyroid examination, and blood was obtained for thyroid function tests $\left[\mathrm{T}_{4}\right.$ assay by equilibrium dialysis (normal range, 10.3-30.6 ng/ $\mathrm{mL}$ ), Quest, Nichols Institute]. The thyroid gland was palpated by a pediatric endocrinologist (C.F. or G.L.F.), and the size was defined as 0 , surgical thyroidectomy; 1 , normal size; 2 , mildly enlarged (each lobe between 2 and $5 \mathrm{~cm}$ ); and 3, greatly enlarged (each lobe $>5 \mathrm{~cm}$ ).

Patients actively followed for thyroid cancer also had serum measurements of Tg (normal range, 2.3-39.6 ng/mL; detection limit, $0.5 \mathrm{ng} / \mathrm{mL}$ ), anti-Tg antibodies (normal range, 0-2.0 IU/mL; Quest, Nichols Institute) and whole body ${ }^{131}$ I uptake. The serum Tg protein level ranged from 0.5 to $2700 \mathrm{ng} / \mathrm{mL}$ (mean, $389.6 \pm 875 \mathrm{ng} / \mathrm{mL}$ ). The ${ }^{131}$ I uptake was based on a standard $5-\mathrm{mCi}^{131} \mathrm{I}$ dose. The median length of time between obtaining the blood sample and thyroid scan was $11 \mathrm{~d}$, and all but one patient (number 34, 59 d) had blood drawn within 2 wk of thyroid scan. The extent of disease at diagnosis was defined according to the classification system of DeGroot et al. (11). Class I disease was confined to the thyroid gland, class II involved regional lymph nodes, class III evidenced either direct extension beyond the capsule or was inadequately resected, and class IV evidenced distant metastases (lung or bone).

Three milliliters of EDTA-anticoagulated whole blood was drawn and placed on ice. Total RNA was extracted using PUREscript (Gentra Systems, Inc, Minneapolis, MN, U.S.A.) according to the manufacturer's suggested guidelines. One microgram of total RNA was reverse transcribed using random hexamer primers and Multiscribe Reverse Transcriptase (Perkin Elmer, Foster City, CA, U.S.A.) (7, 8).

Quantitative RT-PCR was performed as previously described (7). Briefly, Tg mRNA-specific primers spanning a $1.5-\mathrm{kb}$ intron were designed to amplify an $87-\mathrm{bp}$ product (bp 262-348) in the cDNA sequence. The primers used were as follows: sense: 5'-GTGCCAACGGCAGTGAAGT-3'; antisense: 5'-TCTGCTGTTTCTGTAGCTGACAAA-3'; and oligoprobe: 5'-FAM-ACAGACAAGCCACAGGCCGTCCTTAMRA-3'. Each sample was assayed in triplicate with final reaction conditions as follows: $1 \times$ TaqMan Buffer; $0.5 \mathrm{~g} / \mathrm{L}$ gelatin; $0.1 \mathrm{~mL} / \mathrm{L}$ Tween 20; $80 \mathrm{~mL} / \mathrm{L}$ glycerol; $5.5 \mathrm{mM}$ $\mathrm{MgCl}_{2} ; 200 \mu \mathrm{M}$ each dATP, dCTP, and dGTP; $400 \mu \mathrm{M}$ dUTP; $200 \mu \mathrm{M}$ of each primer; $100 \mu \mathrm{M}$ TaqMan oligoprobe; $10 \mathrm{U} / \mathrm{L}$ AmpErase UNG; and $25 \mathrm{U} / \mathrm{L}$ AmpliTaq Gold. Cycling conditions included an initial phase of $2 \mathrm{~min}$ at $50^{\circ} \mathrm{C}$ followed by 10 min at $95^{\circ} \mathrm{C}$ for AmpErase, then the sample was cycled for 40 cycles of $15 \mathrm{~s}$ at $95^{\circ} \mathrm{C}$, followed by $1 \mathrm{~min}$ at $60^{\circ} \mathrm{C}$.

RT-PCR calibration curves using normal thyroid mRNA were constructed using the threshold cycle (defined as the point at which each reaction reaches the logarithmic portion of the PCR curve). The cycle number at which this occurs has been previously validated by our group as proportional to the initial concentration of Tg mRNA present in the blood sample, and the interassay coefficient of variance was $1.6 \%$ with this technique (7). Statistical comparisons were performed using either linear-by-linear association or two-tailed $t$ test and SPSS software (SPSS for Windows 95).

\section{RESULTS}

The clinical details and corresponding Tg mRNA levels for patients with benign thyroid disease are shown in Table 1 . The clinical details of each patient with PTC, including disease status around the time of $\mathrm{Tg}$ mRNA determination, are shown in Table 2 .

Specific Tg mRNA was successfully amplified from 38 of the 42 samples (90\%). As shown in Figure 1, Tg mRNA levels ranged from 3.3 to $104 \mathrm{pg} \mathrm{Eq} / \mu \mathrm{g}$ total thyroid RNA (mean, $28.0 \pm 20.2 \mathrm{pg} \mathrm{Eq} / \mu \mathrm{g}$ total thyroid RNA). All but two patients had levels $<60 \mathrm{pg} \mathrm{Eq} / \mu \mathrm{g}$ total thyroid RNA. The two outliers (defined by SPSS as $>1.5$ times the interquartile range above the third quartile) included one patient with Graves' disease and one patient with Hashimoto's thyroiditis. The patient with 
Table 1. Subjects with benign thyroid disease

\begin{tabular}{|c|c|c|c|c|c|c|c|}
\hline Case & Diagnosis & Age/Sex & Tanner stage & $\begin{array}{c}\text { free } \mathrm{T}_{4}(\mathrm{pM}) \\
(10.3-30.6)\end{array}$ & $\begin{array}{c}\text { TSH }(\mu \mathrm{IU} / \mathrm{mL}) \\
(0.5-4.9)\end{array}$ & $\begin{array}{c}\mathrm{Tg} \\
(\mathrm{ng} / \mathrm{mL}) \\
(2.3-39.6)\end{array}$ & $\begin{array}{c}\text { Tg mRNA (pg Eq/ } \mu \mathrm{g} \text { total } \\
\text { thyroid RNA) }\end{array}$ \\
\hline 1 & Normal & $12 / \mathrm{F}$ & N/A & 13.4 & 3.31 & & 6.6 \\
\hline 3 & Multinodular goiter & $18 / \mathrm{F}$ & $\mathrm{V}$ & 10.7 & 8.04 & 30.6 & $21.8^{*}$ \\
\hline \multicolumn{8}{|c|}{ Mean for multinodular goiter } \\
\hline 14 & Hashimoto's thyroiditis & $16 / \mathrm{F}$ & $\mathrm{V}$ & 14.8 & 0.38 & & 21.0 \\
\hline 18 & Hashimoto's thyroiditis & $18 / \mathrm{F}$ & $\mathrm{V}$ & 20.6 & 0.58 & & 36.5 \\
\hline 19 & Hashimoto's thyroiditis & $20 / \mathrm{F}$ & $\mathrm{V}$ & 16.3 & 0.57 & & 29.0 \\
\hline 8 & Hashimoto's thyroiditis & $18 / \mathrm{F}$ & $\mathrm{V}$ & 21.4 & 1.35 & & 50.0 \\
\hline 12 & Hashimoto's thyroiditis & $13 / \mathrm{F}$ & $\mathrm{V}$ & 17.2 & 1.6 & & 30.2 \\
\hline 20 & Hashimoto's thyroiditis & $16 / \mathrm{F}$ & $\mathrm{V}$ & 10.7 & 2.44 & & 13.8 \\
\hline 15 & Hashimoto's thyroiditis & $12 / \mathrm{F}$ & III & 15.5 & 4.43 & & 13.0 \\
\hline 10 & Hashimoto's thyroiditis & $12 / \mathrm{M}$ & II & 15.8 & 4.52 & & 22.2 \\
\hline 6 & Hashimoto's thyroiditis & $9 / \mathrm{F}$ & III & 15.4 & 4.86 & 0.5 & 23.2 \\
\hline 21 & Hashimoto's thyroiditis & $11 / \mathrm{F}$ & I & 20.6 & 12.93 & & 16.2 \\
\hline 9 & Hashimoto's thyroiditis & $15 / \mathrm{F}$ & $\mathrm{V}$ & 3.1 & 77.6 & & 3.3 \\
\hline 4 & Hashimoto's thyroiditis & $8 / \mathrm{F}$ & $\mathrm{I}$ & 3.6 & 232 & & 82.7 \\
\hline \multicolumn{8}{|c|}{ Mean for Hashimoto's thyroiditis } \\
\hline & & & & & & & $29.4 \pm 17.7$ \\
\hline 33 & Graves' disease & $13 / \mathrm{F}$ & I & 18.1 & 0.01 & & 6.0 \\
\hline 31 & Graves' disease & $12 / \mathrm{M}$ & N/A & 26.1 & 0.01 & & 7.6 \\
\hline 28 & Graves' disease & $12 / \mathrm{M}$ & $\mathrm{N} / \mathrm{A}$ & 27.3 & 0.01 & & 38.4 \\
\hline 30 & Graves' disease & $14 / \mathrm{F}$ & $\mathrm{V}$ & 13.7 & 0.02 & & 9.2 \\
\hline
\end{tabular}

* Patients were previously treated with total thyroidectomy. Residual ${ }^{131}$ Iodine uptake is unknown.

$\mathrm{N} / \mathrm{A}=$ not available from medical record.

Graves' disease (number 23) was a 16-y-old girl with a 2 y history of Graves' disease. She had a modest goiter, was euthyroid while receiving both methimazole and thyroxine, and had elevated TSH receptor antibody (17.8\%; normal range, $0 \%-10 \%$ ). The patient with Hashimoto's thyroiditis (number 4) was an 8-y-old girl with profound hypothyroidism, myxedema, diffusely enlarged sella turcica, a small thyroid gland, and TSH of $232 \mu \mathrm{IU} / \mathrm{mL}$.

There was no significant difference in the Tg mRNA levels for patients with benign and malignant thyroid disease. As shown in Figure 2, there was substantial overlap between patients with PTC and all benign lesions.

Despite the lack of overall correlation between Tg mRNA level and diagnosis, there were important relationships within the group of patients with PTC. All five patients were initially treated with total thyroidectomy $1-87$ mo before determination of peripheral blood Tg mRNA. All except patient 36 had also received multiple adjunctive treatments with ${ }^{131}$ I ablation. As shown in Figure $3 A$, there was a significant correlation between Tg mRNA and Tg protein levels $(r=0.90, p=0.037)$. If the outlier (patient 36, Tg protein $=2700 \mathrm{ng} / \mathrm{mL}$ ) is excluded, there is still a strong correlation $(r=0.84)$ between Tg mRNA and $\mathrm{Tg}$ protein, but too few cases remain to achieve statistical significance. As shown in Figure $3 B$, there was a significant correlation between the Tg mRNA level and the percent ${ }^{131} \mathrm{I}$ uptake on whole body radioiodine scan $(r=0.92, p=0.026)$. Likewise, if patient 36 is excluded from analysis (9.6\% uptake), there is still a strong correlation between Tg mRNA levels and percent ${ }^{131} \mathrm{I}$ uptake $(r=0.80)$, but too few cases remain to achieve statistical significance.

Tg mRNA levels were similar $(p=0.67)$ in boys $(26.9 \pm$ 15.5; range, 5.0-49.4 pg Eq/ $\mu \mathrm{g}$ total thyroid RNA) and girls (28.3 \pm 21.7 ; range, $3.3-104 \mathrm{pg} \mathrm{Eq} / \mu \mathrm{g}$ total thyroid RNA), and, if the two female outliers were excluded, there was essentially complete overlap for both groups. There was no significant correlation between age and Tg mRNA level $(r=$ 
Table 2. Clinical details of five cases of persistent PTC at the time of $T g m R N A$ levels

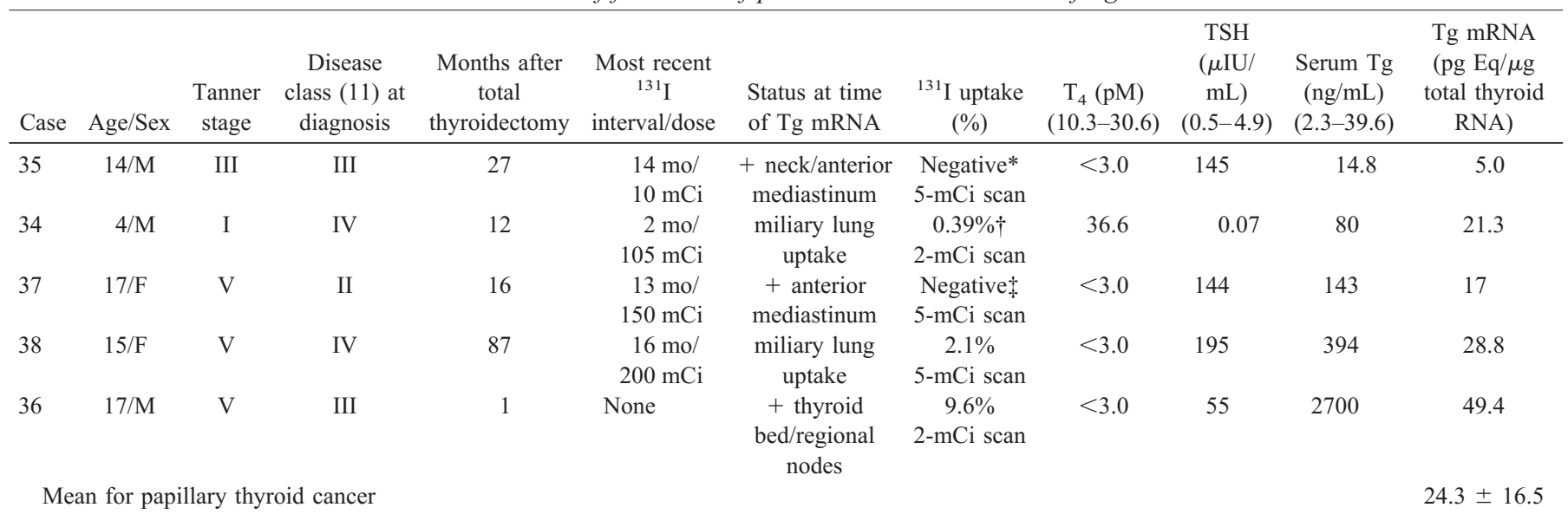

* Negative 5-mCi scan but positive 200-mCi posttreatment scan.

$\dagger$ Blood studies and ${ }^{131}$ I uptake were within 2 wk except for patient 34, whose blood was drawn $59 \mathrm{~d}$ after his scan.

$\$$ Negative 5 -mCi scan but positive 150 -mCi posttreatment scan.

Tg-mRNA DISTRIBUTION

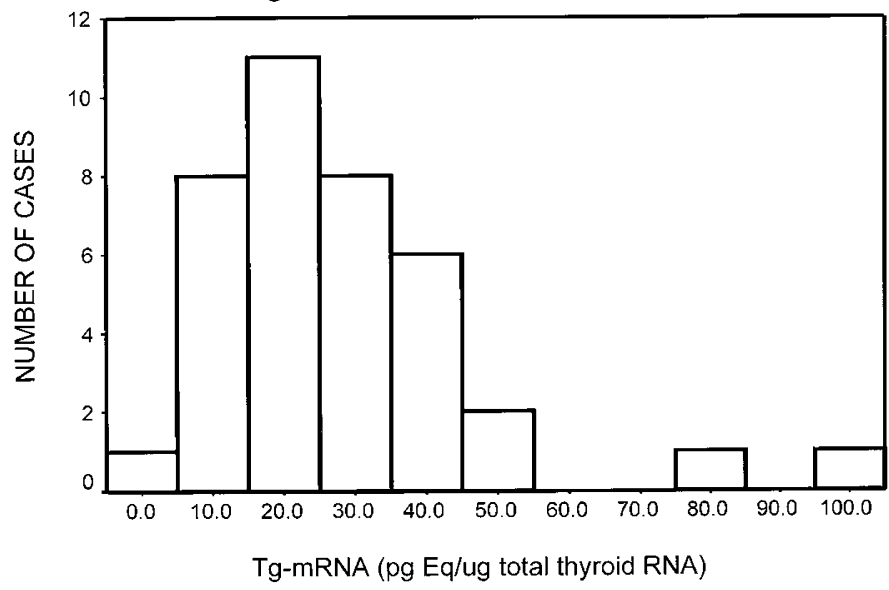

Fig. 1. Frequency distribution of $\mathrm{Tg}$ mRNA levels. Peripheral blood $\mathrm{Tg}$ mRNA levels were measured by RT-PCR in 38 children and adolescents with benign or malignant thyroid disease. Values ranged from 3.3 to $104 \mathrm{pg} / \mathrm{mL}$.

$0.081, p=0.63)$. When analyzed separately for each sex and according to Tanner stage of pubertal development, there was still no correlation between Tg mRNA levels and age (girls, $p=0.094$; boys, $p=0.16$; data not shown).

The relationship between TSH and Tg mRNA was examined in patients with benign thyroid disease. Patients with PTC who had been rendered athyreotic by total thyroidectomy and radioiodine were excluded from analysis because there was no reason to believe that the amount of thyroid cancer remaining in each patient was related to the serum TSH level. There was a significant correlation $(r=0.38, p=0.03)$ between the serum TSH and circulating Tg mRNA levels. However, when the patients with thyroid cancer were included in the analysis, the relationship was no longer valid $[r=0.17, p=0.31$, (data not shown)]. In addition, there was no correlation between $\mathrm{Tg}$ mRNA levels and the level of $\mathrm{T}_{4}$ or anti-Tg antibodies (data not shown).

The relationship between Tg mRNA level and thyroid gland size was also performed after excluding patients with thyroid cancer. This was related to the fact that all had previously
Tg-mRNA BY DIAGNOSIS

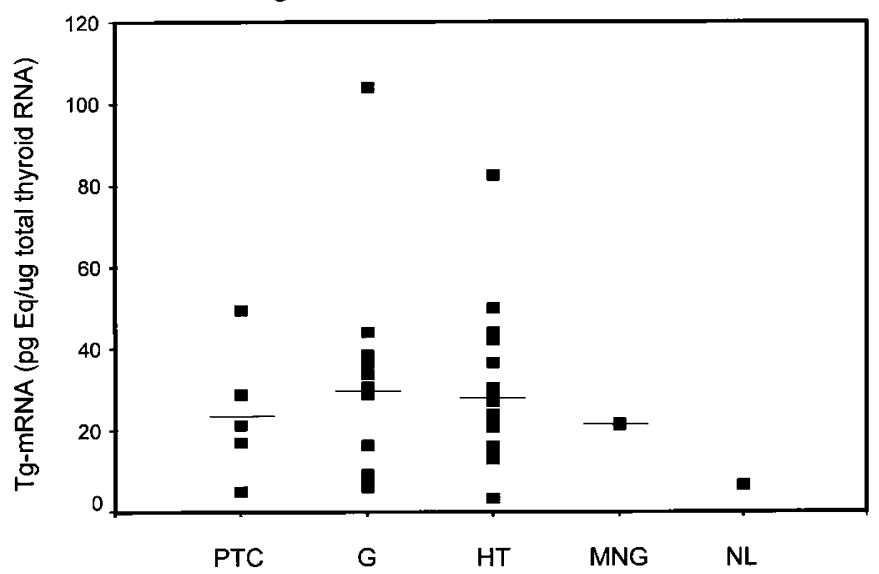

Fig. 2. Relationship between the levels of $\mathrm{Tg}$ mRNA and diagnosis. $\mathrm{Tg}$ mRNA levels were determined in children and adolescents with Hashimoto's thyroiditis (HT, $n=19)$, Graves' disease (G, $n=12)$, metastatic PTC $(n=5)$, multinodular goiter (MNG, $n=2$ ), and normal thyroid (NL, $n=1$ ). Tg mRNA levels were similar in all groups ( $p=$ NS for all comparisons).

undergone total thyroidectomy and the size of any residual disease could not be estimated by palpation of the thyroid bed. Two patients with benign thyroid disease, number 3 (multinodular goiter) and number 32 (Graves' disease) had undergone thyroidectomy, but ${ }^{131} \mathrm{I}$ uptake was unknown. They were included in this analysis with an estimated gland size of 0 . There was no significant correlation between Tg mRNA level and thyroid size ( $p=0.14$, Spearman correlation).

\section{DISCUSSION}

The present study was designed to determine whether the whole blood Tg mRNA levels differ between children with benign and malignant thyroid disease. The secondary goals were to determine whether Tg mRNA levels correlate with diagnosis, age, pubertal development, thyroid size, or the serum levels of $\mathrm{T}_{4}, \mathrm{TSH}$, and $\mathrm{Tg}$ protein in children with thyroid disease. 

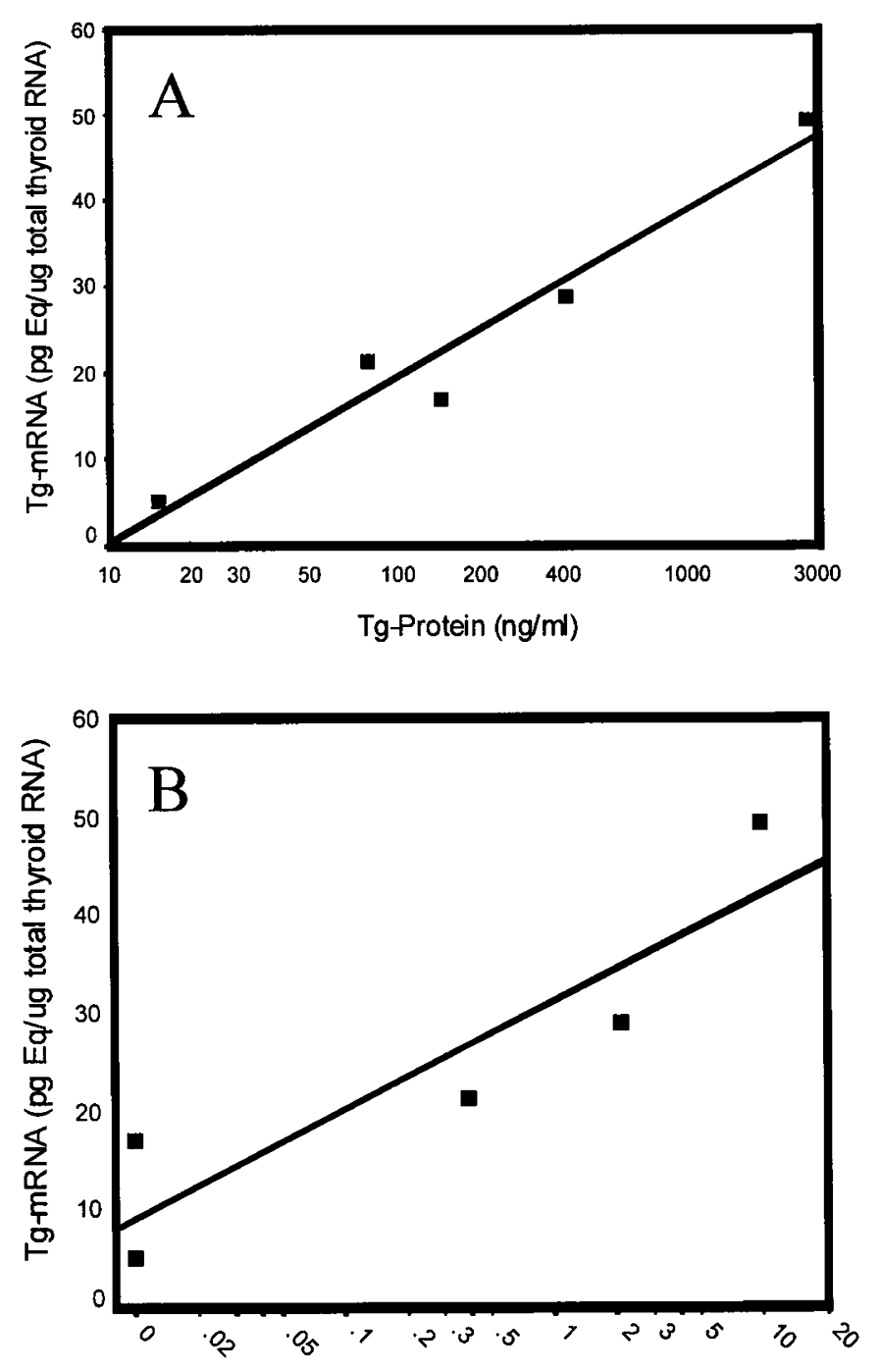

131-IODINE UPTAKE (\%)

Fig. 3. Relationship between $\mathrm{Tg}$ mRNA levels, $\mathrm{Tg}$ protein, and radioactive iodine uptake for thyroidectomized patients with persistent PTC. The whole blood Tg mRNA levels for the five patients with PTC are presented as pg $\mathrm{Eq} / \mu \mathrm{g}$ total thyroid RNA. $A$, Tg mRNA levels are significantly correlated with the serum Tg protein level. $(r=0.90, p=0.037) . B$, Tg mRNA levels are significantly correlated with total body ${ }^{131}$ I uptake $(r=0.92, p=0.026)$. The two patients with negative 5 -mCi scans are entered as $0 \%$ uptake.

Our data show that $\mathrm{Tg}$ mRNA can be successfully amplified from the blood of $90 \%$ (38 of 42 patients) of attempted samples. The four failures were owing to failure to isolate intact RNA, not because of PCR amplification failure. Peripheral blood Tg mRNA levels in children averaged $28.0 \pm 20.2$ $\mathrm{pg} \mathrm{Eq} / \mu \mathrm{g}$ total thyroid RNA with a range from 3.3 to $104 \mathrm{pg}$ $\mathrm{Eq} / \mu \mathrm{g}$ total thyroid RNA. With the exception of two female outliers (one patient with Hashimoto's thyroiditis and one with Graves' disease), the mean and range are similar to our previous findings in adults (8). It should be noted that both outliers had autoimmune thyroid disease. We have previously identified circulating epithelial cells in the peripheral blood of normal subjects that express TSH receptor and Tg protein (6). This observation suggests that benign thyroid cells may gain access into the peripheral circulation. At the present time, we have no explanation for how, and under what circumstances, this occurs. The data in our current study are consistent with the hypothesis that these Tg mRNA-positive cells may be of thyroid origin, and that autoimmune thyroid disease could enhance entry into peripheral blood.

The level of Tg mRNA in peripheral blood of children with benign thyroid lesions was significantly correlated with the serum TSH level $(p=0.03)$. This was true for all patients except those with thyroid cancer. The latter were excluded from analysis because there was no a priori reason to suggest a relationship between TSH and the amount of residual thyroid cancer. These data suggest that Tg mRNA detected in the peripheral blood may be linked to TSH stimulation, which would further support the hypothesis that these cells are of thyroidal origin (6).

Our data found no significant relationships between $\mathrm{Tg}$ mRNA levels and diagnosis, serum $\mathrm{T}_{4}$ levels, or anti-Tg antibody. Furthermore, we found no difference in Tg mRNA levels with respect to sex, age, thyroid size, or Tanner stage of pubertal development. These observations suggest that peripheral blood Tg mRNA levels in children with thyroid disease may be interpreted similar to the results in adults (8). The primary objective of our study was to compare Tg mRNA levels in children with benign and malignant thyroid disease and to determine whether Tg mRNA levels could be used to distinguish malignant from benign thyroid lesions. For this reason, we did not design the study to include normal children. It is possible that a study designed to explore Tg mRNA levels in a normal population might be more sensitive in detecting potential relationships between Tg mRNA levels and age or pubertal status. However, our data find no suggestion of such relationships in children with thyroid disease. Additional studies should be performed to explore these relationships in normal children.

The most important observations in our study relate to previously thyroidectomized patients with persistent PTC. In completely athyreotic adults, we previously showed that patients with no evidence of disease have Tg mRNA levels that are generally $<3 \mathrm{pg} \mathrm{Eq} / \mu \mathrm{g}$ total thyroid RNA. In contrast, adults with metastatic disease have higher values (8). All the children in this study had persistent disease and Tg mRNA levels ranging from 5 to $49.43 \mathrm{pg} \mathrm{Eq} / \mu \mathrm{g}$ total thyroid RNA. In addition, Tg mRNA levels closely correlated with total body tumor burden as determined by whole body ${ }^{131}$ I uptake $(r=$ $0.92, p=0.026)$ and serum Tg protein levels $(r=0.90, p=$ 0.037). Our previous adult studies did not include whole body ${ }^{131}$ I uptake; therefore, the current study provides the first observation of a direct, quantitative relationship between $\mathrm{Tg}$ mRNA levels and total body tumor burden. The power of this study is limited by the small number of children with PTC; however, the correlations are very strong ( $r=0.90$ with $\mathrm{Tg}$ protein and $r=0.92$ with ${ }^{131}$ I uptake). These findings suggest the possibility that Tg mRNA levels might be useful for monitoring children with PTC. However, further study is warranted to confirm these observations in a larger number of subjects, especially children who appear cured of disease.

In conclusion, the current study has shown that Tg mRNA can be successfully amplified from the whole blood of children 
and adolescents with benign or malignant thyroid disease. Tg mRNA levels are similar to those previously reported for adults, and do not appear to vary with sex, age, pubertal development, or diagnosis. For thyroidectomized patients with persistent PTC, the Tg mRNA level is closely correlated with total body tumor burden as determined by the whole body ${ }^{131} \mathrm{I}$ uptake and the serum Tg protein level.

Acknowledgment. The authors thank Peter Clemons, M.D., Merrily Poth, M.D., Catherine Dinauer, M.D., Rita Svec, M.D., and Susan Nunez, M.D., for their assistance in recruiting subjects for this protocol. We also thank Sabita Lahari for her assistance with the RNA extractions. In addition, the authors thank the nurses of the Pediatric Endocrine Clinic for their assistance in obtaining blood from these patients and Robin Howard for her assistance with the statistical analyses.

\section{REFERENCES}

1. Smith B, Selby P, Southgate J, Pittman K, Bradley C, Blair GE 1991 Detection of melanoma cells in peripheral blood by means of reverse transcriptase-polymerase chain reaction. Lancet 338:1227-1229

2. Luppi M, Morselli M, Bandieri E, Federico M, Marasca R, Barozzi P, Ferrari MG Savarino M, Frassoldati A, Torelli G 1996 Sensitive detection of circulating breast cancer cells by reverse transcriptase-polymerase chain reaction. Ann Oncol 7:619624

3. Ghossein RA, Scher HI, Gerald WL, Kelly WK, Curley T, Amsterdam A, Zhang ZF, Rosai J 1995 Detection of circulating tumor cells in patients with localized and metastatic prostatic carcinoma: clinical implications. J Clin Oncol 13:1195-1200

4. Ditkoff BA, Marvin MR, Yemul S, Shi YJ, Chabot J, Feind C, Lo Gerfo PL 1996 Detection of circulating thyroid cells in peripheral blood. Surgery 120:959-965

5. Tallini G, Ghossein RA, Emanuel J, Gill J, Kinder B, Dimich AB, Costa J, Robbins R, Burrow GN, Rosai J 1998 Detection of thyroglobulin, thyroid peroxidase, and RET/PTC1 mRNA transcripts in the peripheral blood of patients with thyroid disease. J Clin Oncol 16:1158-1166

6. Ringel MD, Ladenson PW, Levine MA 1998 Molecular diagnosis of residual and recurrent thyroid cancer by amplification of thyroglobulin messenger ribonucleic acid in peripheral blood. J Clin Endocrinol Metab 83:4435-4442

7. Wingo ST, Ringel MD, Anderson JS, Patel AD, Lukes YD, Djuh YY, Solomon B, Nicholson D, Balducci-Silano PL, Levine MA, Francis GL, Tuttle RM 1998 Quantitative RT-PCR measurement of thyroglobulin mRNA in peripheral blood of normal subjects. Clin Chem 45:785-789

8. Ringel MD, Balducci-Silan PL, Anderson JS, Spencer CA, Silverman J, Sparling YH, Francis GL, Burman KD, Wartofsky L, Ladenson PW, Levine MA, Tuttle RM 1999 Quantitative reverse transcriptase polymerase chain reaction of circulating thyroglobulin messenger RNA for monitoring patients with thyroid carcinoma. J Clin Endocrinol Metab 84:4037-4042

9. Spencer CA, Takeuchi M, Kazaroxyan, Wang CC, Guttler RB, Singer PA, Fatemi S, LoPresti JS, Nicoloff JT 1998 Serum thyroglobulin autoantibodies: prevalence, influence on serum thyroglobulin measurement, and prognostic significance in patients with differentiated thyroid carcinoma. J Clin Endocrinol Metab 83:1121-1127

10. Hedinger C, Williams ED, Sobin LH 1989 The WHO histological classification of thyroid tumors: a commentary on the second edition. Cancer 63:908-911

11. DeGroot LJ, Kaplan EL, McCormick M, Strauss FH 1990 Natural history, treatment, and course of papillary thyroid carcinoma. J Clin Endocrinol Metab 71:414-424 